\title{
ZACHOWANIA ZDROWOTNE PACJENTÓW Z CHOROBĄ ZWYRODNIENIOWĄ STAWÓW LECZONYCH NA ODDZIALE ORTOPEDII
}

\section{HEALTH BEHAVIORS OF PATIENTS WITH OSTEOARTHRITIS TREATED AT THE ORTHOPEDIC DEPARTMENT}

\author{
Renata Piotrkowska ${ }^{1, a}$, Piotr Jarzynkowski ${ }^{1, b}$, Sylwia Terech-Skóra ${ }^{1, c}$, Wioletta Mędrzycka- \\ -Dąbrowska ${ }^{2, d}$

\footnotetext{
${ }^{1}$ Zakład Pielęgniarstwa Chirurgicznego, Wydział Nauk o Zdrowiu z Oddziałem Pielęgniarstwa i Instytutem Medycyny Morskiej i Tropikalnej, Gdański Uniwersytet Medyczny

${ }^{2}$ Zakład Pielęgniarstwa Anestezjologicznego i Intensywnej Opieki, Wydział Nauk o Zdrowiu z Oddziałem Pielęgniarstwa i Instytutem Medycyny Morskiej i Tropikalnej, Gdański Uniwersytet Medyczny
}

${ }^{\text {a }}$ https://orcid.org/0000-0001-6512-255X

${ }^{\mathrm{b}} \mathrm{https://orcid.org/0000-0003-0546-6195}$

${ }^{c} \mathrm{https} / / /$ orcid.org/0000-0002-7099-4739

${ }^{d}$ https://orcid.org/0000-0001-8377-4893

DOI: https://doi.org/10.20883/pielpol.2020.1

\section{STRESZCZENIE}

Wstęp. Choroba zwyrodnieniowa stawów (osteoartroza; ang osteoarthritis - OA) to najczęstsza przewlekła choroba stawów i główna przyczyna dolegliwości bólowych w układzie mięśniowo-szkieletowym wśród populacji w krajach rozwiniętych. Światowa Organizacja Zdrowia (World Health Organization) uznała, iż jest to jedno z ważniejszych zagrożeń cywilizacyjnych. Obecnie ocenia się, że w Polsce choruje na osteoartrozę około 2 miliony osób.

Cel. Celem pracy była ocena poziomu zachowań zdrowotnych wśród pacjentów ze zdiagnozowaną chorobą zwyrodnieniową stawów leczonych na oddziale ortopedii.

Materiał i metody. Badaną grupę stanowiło 58 pacjentów z klinicznie zdiagnozowaną chorobą zwyrodnieniową stawów, zaplanowanych do leczenia operacyjnego na oddziale ortopedii w szpitalu w Gdańsku. W pracy zastosowano metodę sondażu diagnostycznego. Narzędziem badawczym był kwestionariusz ankiety własnej konstrukcji oraz kwestionariusz Inwentarz Zachowań Zdrowotnych (IZZ) autorstwa Zygfryda Juczyńskiego.

Wyniki. Średni uzyskany wynik dla badanej populacji to 91,28 pkt. Najniższy uzyskany wynik w grupie badanych wynosił 65 pkt.

Wnioski. Osoby ze zdiagnozowaną chorobą zwyrodnieniową stawów leczone na oddziale ortopedii prezentują wysoki poziom zachowań zdrowotnych. Czynniki społeczno-demograficzne oraz kliniczne nie wpływają istotnie na poziom zachowań zdrowotnych.

SŁOWA KLUCZOWE: zachowania zdrowotne, choroba zwyrodnieniowa, pacjent.

\begin{abstract}
Introduction. Osteoarthritis is the most common chronic disease of the joints and the main cause of pain in the musculoskeletal system among populations in developed countries. The World Health Organization recognized it is one of the most important civilizational threats. Currently, about 2 million people are estimated to suffer from osteoarthritis in Poland.

Aim. The aim of the study was to assess the level of health behaviors among patients diagnosed with osteoarthritis treated at the orthopedic department.

Material and methods. The study group consisted of $58 \mathrm{pa}-$ tients with clinically diagnosed osteoarthritis, planned for surgical treatment at the orthopedic department in hospital in Gdansk. The method of a diagnostic survey was used in the study. The research tool was the author's own questionnaire and the Inventory of Health Behaviors questionnaire by Zygfryd Juczyński.

Results. The average result obtained for the studied population is 91.28 points. The lowest result obtained in the group of respondents was 65 points.

Conclusions. People diagnosed with osteoarthritis treated at the orthopedic department present a high level of health behaviors. Socio-demographic and clinical factors do not significantly influence the level of health behaviors.
\end{abstract}

KEYWORDS: health behaviors, osteoarthritis, patient. 


\section{Wprowadzenie}

Choroba zwyrodnieniowa stawów (osteoartroza; ang. osteoarthritis - OA) to najczęstsza przewlekła choroba stawów i główna przyczyna dolegliwości bólowych w układzie mięśniowo-szkieletowym wśród populacji w krajach rozwiniętych. Światowa Organizacja Zdrowia (World Health Organization) uznała, iż jest to jedno z ważniejszych zagrożeń cywilizacyjnych. Obecnie ocenia się, że około 2 miliony Polaków choruje na osteoartrozę [1].

Pojawienie się objawów klinicznych oraz przebieg zmian zwyrodnieniowych jest zależne od konstelacji czynników ryzyka OA. Występowanie OA wzrasta wraz z wiekiem, a zmiany zwyrodnieniowe najczęściej dotyczą kobiet. Otyłość to czynnik mający istotny wpływ na zmiany zwyrodnieniowe stawów biodrowych, kolanowych i zwyrodnień stawów rąk. Kolejnymi czynnikami ryzyka są: czynniki genetyczne (guzki Boucharda i Heberdena), które prowadzą do zaburzeń struktury kolagenu typu II, wysoka wartość BMD (Bone Mineral Density). Czynniki mechaniczne, które są związane z mikrourazami, zmierzają do zmian degeneracyjnych [2]. Elementy ryzyka związane z wtórną chorobą zwyrodnieniową stawów to: neuropatia - uszkodzenia rdzenia kręgowego, cukrzyca, mechaniczne - zmiany wywołane makrourazami i mikrourazami również po ingerencji chirurgicznej, zaburzenia składu krwi doprowadzające do hemartrozy, choroby zapalne - stawy objęte procesem zapalnym w zakażeniu lub przebiegu reumatoidalnego zapalenia stawów oraz czynniki metaboliczne - choroba Wilsona, ochronoza, krystlopatie, zespół Cushinga [3]. Objawy kliniczne ukazują się około 40. roku życia. Głównym objawem jest ból o swoistym charakterze mechanicznym. Ma on związek z wykonywanym ruchem (ból stawowy). W miarę postępowania choroby ujawnia się objaw sztywności po tzw. okresie unieruchomienia, który przeważnie nie przekracza 30 minut. Utrudnienie ruchomości w stawie zazwyczaj prowadzi do zaników mięśniowych. Objawami dotyczącymi najczęściej zaawansowanej postaci OA są: trzeszczenia podczas ruchów, tkliwość stawu w badaniu palpacyjnym, zniekształcenie oraz poszerzenie obrysów stawu i występowanie wysięku w jamie stawowej. Częste objawy kliniczne choroby zwyrodnieniowej stawów obejmują stawy kolanowe, biodrowe, drobne stawy rąk i stawy kręgosłupa [4].

Zachowania zdrowotne to konkretne działania człowieka podejmowane przez niego w związku z własnym stanem psychofizycznym. Czynności takie dzieli się na sprzyjające zdrowiu, czyli prozdrowotne, oraz szkodliwe dla zdrowia - antyzdrowotne. W skład tych pierwszych wchodzą: właściwe nawyki żywieniowe, zachowania profilaktyczne, praktyki zdrowotne, takie jak np.: podejmowanie aktywności fizycznej, oraz pozytywne nastawienie psychiczne. O działaniach szkodliwych dla zdrowia świadczyć może palenie tytoniu czy picie alkoholu [5]. Jednym z najważniejszych elementów zachowań zdrowotnych u chorych z chorobą zwyrodnieniową stawów jest aktywność fizyczna. Stosowanie różnego rodzaju ćwiczeń fizycznych wiąże się ze zmniejszeniem natężenia bólu oraz poprawą sprawności motorycznej. Wykonywanie ćwiczeń wzmacniających, rozciągających i aerobowych, w porównaniu z innymi rodzajami ćwiczeń, może być u tych chorych najskuteczniejsze. Według T. Kostki zasadniczą rolę odgrywa aktywność ruchowa i prawidłowe odżywianie. Głównym korzystnym oddziaływaniem podejmowanej aktywności ruchowej jest wydłużenie okresu niezależności i sprawności fizycznej, a zatem i poprawa jakości życia [6].

Zachowania zdrowotne w doświadczaniu choroby charakteryzują się świadomością poczucia choroby. Towarzyszą zarówno bezobjawowemu przebiegowi choroby oraz obiektywnie stwierdzanym dolegliwościom. Podczas doświadczania choroby mogą wystąpić następujące zachowania: podejmowanie postawy biernej wobec choroby, oczekiwanie, że dolegliwości ustąpią same, samoleczenie, wycofanie się z pełnionych ról społecznych. Trzecim z kolei stanem są zachowania zdrowotne w roli chorego. Odnoszą się do sytuacji, gdy jednostka doświadczająca jednoznacznych objawów choroby stara się o ich usunięcie. Tu wyróżnia się kilka zachowań: współdziałanie z personelem medycznym w procesie leczenia, poszukiwanie pomocy medycznej, niewykonywanie lub wykonanie otrzymanych zaleceń [7-8].

\section{Cel pracy}

Celem pracy była ocena poziomu zachowań zdrowotnych wśród pacjentów ze zdiagnozowaną chorobą zwyrodnieniową stawów leczonych na oddziale ortopedii.

\section{Materiał i metody}

Badaną grupę stanowiło 58 pacjentów z klinicznie zdiagnozowaną chorobą zwyrodnieniową stawów, zaplanowanych do leczenia operacyjnego na oddziale ortopedii w szpitalu w Gdańsku. Badania miały charakter dobrowolny i anonimowy. Wszystkie osoby wyraziły zgode na udział w badaniu oraz zostały zapoznane z celem i procedurą badania. $\mathrm{Na}$ ich przeprowadzenie uzyskano zgodę Niezależnej Komisji Bioetycznej ds. Badań Naukowych przy Gdańskim Uniwersytecie Medycznym (NKBB/121/2018). Okres prowadzenia badań trwał od lutego do maja $2018 \mathrm{r}$.

W pracy zastosowano metodę sondażu diagnostycznego. Narzędziem badawczym był kwestionariusz ankiety własnej konstrukcji pozwalający na zebranie 
danych społeczno-demograficznych oraz Inwentarz Zachowań Zdrowotnych (IZZ) autorstwa Zygfryda Juczyńskiego. W IZZ chorzy mówili, jak często realizują jedną z 24 czynności związanych ze zdrowiem. Do oceny użyto pięciostopniową skalę, w której 1 oznacza „,prawie nigdy”, 2 - ,,rzadko", 3 - ,,od czasu do czasu”, 4 - „,często”, 5 - ,,prawie zawsze”. Inwentarz Zachowań Zdrowotnych jest testem przeznaczonym dla osób dorosłych i pozwala określić poziom zachowań zdrowotnych. Uzyskane odpowiedzi ukazują ogólne nasilenia zachowań zdrowotnych. Następnie można określić poziom nasilenia 4 kategorii zachowań zdrowotnych: nawyki żywieniowe, zachowania profilaktyczne, praktyki zdrowotne oraz pozytywne nastawienie psychiczne. Odczytanie wyników polega na zliczeniu wartości liczbowych wszystkich pytań. Wylicza się ogólny wskaźnik zachowań zdrowotnych, przedstawiając wartości od 24 do 120 punktów. Im wyższa liczba punktów, tym większy poziom deklarowanych zachowań zdrowotnych. Następnie wskaźnik jest przeliczny na jednostki standaryzowane (steny). Skala stenowa to liczby naturalne od 1 do 10, z czego steny od 7-10 to wyniki wysokie, 5-6 to wyniki przeciętne, a steny od 1-4 to wartości niskie. Wskaźnik uzyskany w każdej z czterech wyżej wymienionych kategorii to średnia liczba punktów, którą otrzymuje się na podstawie pytań odpowiadających każdej z kategorii zachowań zdrowotnych.

Wszystkie obliczenia statystyczne zostały przeprowadzone przy użyciu pakietu statystycznego IBM SPSS 23 oraz arkusza kalkulacyjnego Excel 2013. Zmienne typu jakościowego zostały przedstawione za pomocą liczności oraz wartości procentowych. Zmienne ilościowe zostały scharakteryzowane za pomocą średniej arytmetycznej i odchylenia standardowego. Istotność różnic pomiędzy dwiema grupami sprawdzono testem U Manna-Whitneya i testem t-Studenta, a pomiędzy więcej niż dwiema grupami testem Kruskala-Wallisa. W celu stwierdzenia powiązania siły oraz kierunku między zmiennymi zastosowano analizę korelacji, obliczając współczynniki korelacji Spearmana. We wszystkich obliczeniach za poziom istotności przyjęto $p<0,05$.

\section{Wyniki}

Badaną grupę stanowiło 58 pacjentów ze zdiagnozowaną chorobą zwyrodnieniową stawów. W badaniu wzięło udział 55,2\% ( $N=32$ ) kobiet i 44,8\% ( $=26)$ mężczyzn. Wiek badanych wahał się od 24. do 91. roku życia. Najliczniejszą grupę stanowili chorzy w przedziale wiekowym od 55. do 70. roku życia. Średnia wieku badanych wyniosła 67,60 lat $(S D=11,31)$. Większość stanowili mieszkańcy dużych miast $62,1 \%$, osoby pozostające w związku małżeńskim (69\%). Największą grupę stanowili respondenci z wykształceniem średnim 34,5\%.
Ponad połowę chorych (66\%) zakwalifikowano do alloplastyki stawu biodrowego, a 34\% do alloplastyki stawu kolanowego. Duża część badanych $(44,8 \%)$ miała nadwage, 43,1\% - prawidłową masę cała, 10,3\% niedowagę, a tylko 1,7\% - chorych otyłość.

Na pytanie, czy zachowania zdrowotne mogą przyczynić się do zmniejszenia ryzyka wystąpienia choroby zwyrodnieniowej stawów, zdecydowana większość pacjentów (58,9\%) odpowiedziała twierdząco. Pozostała część respondentów zaprzeczyła lub nie wyraziła zdania. Prawie połowa badanych (44,8\%) odpowiedziała, że wykonywana praca powoduje u nich obciążenie stawów. Ponad połowa chorych $(55,2 \%)$ odczuwa ból często, a 36,2\% czuje ból zawsze. Częściowo ograniczony zakres ruchów w stawach ma aż 58,6\% badanych, tylko 10,3\% pacjentów twierdzi, że posiada pełny zakres ruchu.

Większość ankietowanych na chorobę zwyrodnieniową stawów zachorowała między 40. a 60. rokiem życia. Najwięcej ankietowanych deklarowało, że choruje powyżej 10 lat (46,6\%), 22,4\% badanych choruje około 5 lat.

Suma wszystkich punktów ze skali IZZ mieści się w granicach od 24 do 120 punktów. Im wyższy wynik, tym większe nasilenie deklarowanych zachowań zdrowotnych. Ogólny wskaźnik po przekształceniu na jednostki standaryzowane podlega interpretacji stosownie do właściwości charakteryzujących skalę stenową. Wyniki w granicach 1-4 stena przyjęto traktować jako wyniki niskie, 5-6 stena traktuje się jako przeciętne, a 7-10 stena jako wysokie, co odpowiada obszarowi ok. 33\% wyników najniższych. Średni uzyskany wynik dla badanej populacji to 91,28 pkt. Najniższy uzyskany wynik w grupie badanych wynosił 65 punktów, najwyższy 120 .

Prawidłowe nawyki żywieniowe to przede wszystkim rodzaj i jakość spożywanej żywności, np.: owoce, warzywa, pełnoziarniste pieczywo. 37,4\% respondentów deklaruje prawidłowe nawyki żywieniowe jako często spełniane, a ,,prawie zawsze" prawidłowe nawyki żywieniowe stosuje 26,7\% osób. Prawidłowe nawyki żywieniowe ,od czasu do czasu" stosuje 23,3 \% badanych (Tabela 1).

Tabela 1. Prawidłowe nawyki żywieniowe Table 1. Correct eating habits

\begin{tabular}{lcc}
\hline \multicolumn{1}{c}{$\begin{array}{c}\text { Prawidłowe nawyki żywieniowe/ } \\
\text { Correct eating habits }\end{array}$} & N & $\%$ \\
\hline Prawie nigdy/Almost never & 1 & 2,0 \\
Rzadko/Rarely & 6 & 10,6 \\
Od czasu do czasu/Occasionally & 13 & 23,3 \\
Często/Often & 22 & 37,4 \\
Prawie zawsze/Almost always & 16 & 26,7 \\
Razem/Total & 58 & 100 \\
\hline
\end{tabular}

Źródło: opracowanie własne

Source: author's own analysis 
Pozyskiwanie informacji dotyczących choroby i zdrowia oraz przestrzeganie zaleceń lekarskich to zachowania profilaktyczne. Tylko 35,9\% często stosuje zachowania profilaktyczne, ,,prawie zawsze” $32,2 \%$ a ,,prawie nigdy" 2,3\% respondentów (Tabela 2 ).

Tabela 2. Zachowania profilaktyczne

Table 2. Preventive behaviours

\begin{tabular}{lcc}
\hline \multicolumn{1}{c}{$\begin{array}{c}\text { Zachowania profilaktyczne/ } \\
\text { Preventive behavior }\end{array}$} & $\mathrm{N}$ & $\%$ \\
\hline Prawie nigdy/Almost never & 1 & 2,3 \\
Rzadko/Rarely & 7 & 11,5 \\
Od czasu do czasu/Occasionally & 10 & 18,1 \\
Często/Often & 21 & 35,9 \\
Prawie zawsze/Almost always & 19 & 32,2 \\
Razem/Total & 58 & 100 \\
\hline
\end{tabular}

Źródło: opracowanie własne

Source: author's own analysis

Pozytywne nastawienie psychiczne włącza czynniki psychologiczne, takie jak: uniknie sytuacji wpływających stresogennie i przygnębiająco, długotrwałych stresów i napięć oraz silnych emocji. Pozytywne nastawienie psychiczne często ma $34,8 \%$ badanych, a ,,prawie zawsze" - 30,2\% (Tabela 3).

Tabela 3. Pozytywne nastawienie psychiczne Table 3. Positive mental attitude

\begin{tabular}{lcc}
\hline $\begin{array}{c}\text { Pozytywne nastawienie psychiczne/ } \\
\text { Positive mental attitude }\end{array}$ & N & $\%$ \\
\hline Prawie nigdy/Almost never & 1 & 2,0 \\
Rzadko/Rarely & 5 & 9,5 \\
Od czasu do czasu/Occasionally & 14 & 23,6 \\
Często/Often & 20 & 34,8 \\
Prawie zawsze/Almost always & 18 & 30,2 \\
Razem/Total & 58 & 100 \\
\hline
\end{tabular}

Źródło: opracowanie własne

Source: author's own analysis

Praktyki zdrowotne zawierają codzienne nawyki związane z rekreacją, aktywnością fizyczną oraz snem. $34,5 \%$ badanych praktykuje je często, 31\% chorych prawie zawsze. Tylko 3,2\% udzieliła odpowiedzi ,,prawie nigdy", 12,9\% zaznaczyło odpowiedz „,rzadko", a 17,5\% osób ,,od czasu do czasu" (Tabela 4).

Tabela 4. Praktyki zdrowotne

Table 4. Health practices

\begin{tabular}{lcc}
\hline \multicolumn{1}{c}{$\begin{array}{c}\text { Praktyki zdrowotne/ } \\
\text { Health practices }\end{array}$} & N & $\%$ \\
\hline Prawie nigdy/Almost never & 2 & 3,2 \\
Rzadko/Rarely & 7 & 12,9 \\
Od czasu do czasu/Occasionally & 10 & 17,5 \\
Często/Often & 20 & 34,5 \\
Prawie zawsze/Almost always & 19 & 31,9 \\
Razem/Total & 58 & 100 \\
\hline
\end{tabular}

Źródło: opracowanie własne

Source: author's own analysis
Wnioskowania o zgodności wewnętrznej skal kwestionariusza dokonano, obliczając współczynnik zgodności Alfa Cronbacha. Jest to miara określająca spójność pozycji wchodzących w skład danej skali. Wynik wskazywał na zadowalający $\alpha=0,86$. Oznacza to, że jest duże podobieństwo pomiędzy poszczególnymi odpowiedziami, ponieważ osoby badane podobnie udzielają odpowiedzi na poszczególne pytania.

Płeć badanych nie różnicuje ich zachowań zdrowotnych. Wśród kobiet średnia uzyskanych punktów wyniosła $\mathrm{M}=$ 92,97 pkt, a u mężczyzn $\mathrm{M}=90,73$ pkt. Wykształcenie nie ma wpływu na zachowania zdrowotne wśród badanych. Średnia wyników dla osób z wykształceniem podstawowym wyniosła $\mathrm{M}=94,33$ pkt, zawodowym $M=90,43$ pkt, średnim $M=90,7$ pkt oraz dla osób z wykształceniem wyższym $\mathrm{M}=94,15$ pkt. Wiek respondentów nie ma związku z zachowaniami zdrowotnymi $r \mathrm{HO}=0,27$; $<<0,05$. Miejsce zamieszkania nie ma wpływu na zachowania zdrowotne wśród badanych. Mieszkańcy wsi zdobyli średnio $M=93,8$ punktów, miast do 50 tysięcy mieszkańców $M=89,67$ pkt. Natomiast mieszkańcy miast powyżej 50 tysięcy $M=92,22$ pkt.

Palenie tytoniu nie ma wpływu na zachowania zdrowotne wśród badanych. Badani niepalący tytoniu otrzymali średnio $\mathrm{M}=92,72$ pkt, a palący $\mathrm{M}=82,75$ pkt. Bierni palacze uzyskali średnio $M=91,33$ pkt.

Czas trwania choroby nie ma wpływu na zachowania zdrowotne wśród badanych. Pacjenci chorujący do 5 lat otrzymali średnio $M=92,05$ pkt. Badani chorujący w przedziale od 5 do 10 lat uzyskali $M=94,76$ pkt. Grupa chorująca powyżej 10 lat zdobyła $M=90,55$ pkt.

Rodzaj zabiegu operacyjnego nie ma wpływu na zachowania zdrowotne wśród badanych. Chorzy zakwalifikowani do alloplastyki stawu biodrowego uzyskali $\mathrm{M}=91,97$ pkt, natomiast grupa chorych zakwalifikowana do alloplastyki stawu kolanowego $\mathrm{M}=$ 91,95 pkt.

\section{Dyskusja}

Badania dotyczyły oceny poziomu zachowań zdrowotnych u pacjentów z chorobą zwyrodnieniową stawów przyjętych do oddziału ortopedii celem leczenia operacyjnego. Pacjenci byli poddani badaniu w dniu przyjęcia do oddziału i uzyskali wyniki IZZ na poziomie wysokim. Z przeprowadzonych badań wynika, iż wysoki poziom zachowań zdrowotnych prezentuje 44,8\% respondentów, przeciętny - 39,7\%, natomiast niski poziom $13,8 \%$ chorych. Średnia poziomu pozytywnych zachowań zdrowotnych wśród ankietowanych jest wysoka i wynosi $\mathrm{M}=91,28$ pkt.

Obecnie ocenia się, że około 2 miliony Polaków choruje na osteoartrozę. Towarzyszą im często silne dolegliwości bólowe, które w konsekwencji wpływają 
na kontakty społeczne, stan psychiczny oraz emocjonalny chorych [3, 9]. W grupie badanych ból w 55,2\% występuje „,często”, a 36,2\% respondentów odczuwa ból „,zawsze”. Podobne wyniki osiągnęli Majda i wsp. [1], którzy badając jakość życia pacjentów z chorobą zwyrodnieniową stawów biodrowych potwierdzają, iż ból przed zabiegiem operacyjnym jest częstym i silnym objawem. Zmiany patologiczne wywołane przez chorobę zwyrodnieniową mają charakter nieodwracalny oraz wymagają indywidualnego specjalistycznego postępowania. Według danych trwałe ograniczenie ruchomości stawów potwierdza ponad 80\% pacjentów [10]. W badaniach własnych aż 58,6\% osób ma częściowo ograniczony zakres ruchów w stawach. W konsekwencji przewlekłej i długotrwałej destrukcji stawu często jedynym sposobem leczenia jest zabieg operacyjny [11].

Choroba zwyrodnieniowa stawów jest ściśle powiązana z wiekiem fizjologicznym, co potwierdzili Kuciel-Lewandowska i wsp. [12]. W badaniu autorów pracy średnia wieku ankietowanych wyniosła 67,6 lat, a najstarszy pacjent miał 91 lat.

Ryzyko zachorowania na chorobę zwyrodnieniową stawów ma nie tylko podłoże genetyczne. Czynnikami, które predysponują do powstania choroby, są: urazy, wady budowy, mikrourazy, późny wiek, płeć, aktywność fizyczna, wykonywany zawód oraz otyłość. Wyniki badań w ostatnich latach pokazują istotny wpływ otyłości na występowanie choroby zwyrodnieniowej stawów [13]. Spośród badanych aż 44,8\% ma nadwage, a $43,1 \%$ prawidłową wagę ciała. W opinii autorów tak dobre wyniki są prawdopodobnie osiągnięte poprzez okres przygotowywania chorych do zabiegu operacyjnego. Masa ciała ma istotny wpływ na długość prawidłowego działania endoprotezy. Zatem zespół specjalistów przykłada szczególną wagę do tego, by pacjenci osiągnęli optymalną masę ciała. Dane z piśmiennictwa potwierdzają, że przeważająca liczba chorych z chorobą zwyrodnieniową stawów odczuwa obniżony nastrój i poczucie izolacji społecznej [14]. W badaniach własnych nie potwierdzono tej tezy. Ankietowani prezentują pozytywne nastawienie psychiczne. W szczególności wysoko pacjenci ocenili posiadanie przyjaciół i uregulowane życie rodzinne oraz poważne traktowanie wskazówek od osób wyrażających zaniepokojenie ich stanem zdrowia. Ostatnim i równie istotnym zachowaniem jest przestrzeganie zachowań profilaktycznych. Badani uzyskali wysokie wyniki w tym zakresie dzięki unikaniu przeziębień, regularnemu zgłaszaniu się na badania lekarskie oraz stosowaniu się do zaleceń lekarskich. Dzieje się tak dlatego, że chorzy przed przyjęciem do oddziału są między innymi zobligowani do posiadania wyników wymazu z nosogardzieli wraz z antybiogra- mem, badania ogólnego moczu oraz zaświadczenia od stomatologa o braku ognisk zapalnych [15-17].

Przedstawione wyniki wykazały wysoki poziom zachowań zdrowotnych wśród badanych, nie zależy on od wieku, płci, miejsca zamieszkania, palenia tytoniu oraz czasu trwania choroby. Zdecydowana większość nie pali papierosów, stosuje zbilansowaną dietę, prezentuje pozytywne nastawienie psychiczne oraz przestrzega zaleceń lekarskich.

\section{Wnioski}

1. Osoby ze zdiagnozowaną chorobą zwyrodnieniową stawów leczone w oddziale ortopedii prezentują wysoki poziom zachowań zdrowotnych.

2. Czynniki społeczno-demograficzne oraz kliniczne nie wpływają istotnie na poziom zachowań zdrowotnych badanych.

3. Chorzy dbają o prawidłowe odżywianie i przestrzegają zachowań profilaktycznych. Większość badanych ma bardzo dobrą kondycję psychiczną.

4. Praktyki zdrowotne badanych polegają na ograniczaniu palenia tytoniu oraz poświęcaniu odpowiedniej ilości czasu na odpoczynek i sen.

5. Diagnoza zachowań zdrowotnych i kształtujących je czynników pozwoli na opracowanie skutecznych programów edukacji zdrowotnej pacjentów z chorobą zwyrodnieniową stawów.

\section{Piśmiennictwo}

1. Majda A, Walas K, Gawełek A. Jakość życia pacjentów z chorobą zwyrodnieniową stawów biodrowych. Probl Pielęg. 2013; 21(1): 29-37.

2. Łapaj Ł, Kokoszka P, Jurga M, Markuszewski J, WieruszKozłowska M. Jakość życia u chorych przed i po endoprotezoplastyce stawu biodrowego. Chir Narz Ruchu Ortop Pol. 2007; 4: 269-274.

3. Johnson VL, Hunter DJ. The epidemiology of osteoarthritis. Best Pract Res Clin Rheumatol. 2014; 28(1): 5-15.

4. Rocławski M, Kolarz K, Treder M, Mazurek T, Pankowski R. Prospektywne badanie jakości życia uwarunkowanej stanem zdrowia u pacjentów po alloplastyce całkowitej stawu biodrowego w 2-letnim okresie obserwacji. Ann Acad Med Gedan. 2009; 39: 115-121.

5. Tiszczenko E, Surmach M, Piecewicz-Szczęsna H. Zachowania zdrowotne jako kluczowy czynnik zdrowia. Zdr Publ. 2009; 119(1): 86-89.

6. Kostka T. Pomyślne starzenie się. Puls Med. 2006; 7 (130).

7. Ślusarska B, Nowicki G. Zachowania zdrowotne w profilaktyce chorób układu krążenia wśród osób pracujących. Probl Hig Epidemiol. 2010; 91(1): 34-40.

8. Książek J. Jarzynkowski P. Piotrkowska R. Wybrane elementy stylu życia pielęgniarek operacyjnych. Med Rodz. 2015; 3(18): 103-109.

9. Sierakowska M, Wróblewska M, Lewko J. Ocena problemów zdrowotnych pacjentów z chorobą zwyrodnieniową stawów oraz zapotrzebowania na wsparcie i edukację zdrowotną. Probl Pielęg. 2011; 19(3): 353-360. 
10. Bazalińska D, Maliborska E, Więch P. Najczęstsze problemy zdrowotne w okresie okołooperacyjnym u osób poddawanych alloplastyce stawu biodrowego. Probl Pielęg. 2017; 25(1): 1-7.

11. Musumeci G, Concetta Aiello F, Szychlinska MA, Di Rosa M, Castrogiovanni P, Mobasheri A. Osteoarthritis in the XXIst Century: Risk Factors and Behaviours that Influence Disease Onset and Progression. Int J Mol Sci. 2015; 16: 6093-6112.

12. Kuciel-Lewandowska J, Marcinkiewicz N, Kierzek A, Pozowski A, Ratajczak B, Boerner E. Zdrowy styl życia a choroba zwyrodnieniowa stawów. Acta Bio-Op Inform Med. 2012; 18(4): 229-233.

13. Jasik A, Tałałaj M. Otyłość a choroba zwyrodnieniowa stawów. Post N Med. 2013; 5B: 14-18.

14. Hamer M, Stamatakis E, Steptoe A. Dose-response relationship between physical activity and mental health: the Scottish Health Survey. Br J Sports Med. 2009; 43(14): 1111-1114.

15. Fransen M, McConnell S. Land-based exercise for osteoarthritis of the knee: a metaanalysis of randomized controlled trials. J Rheumatol. 2009; 36(6): 1109-1117.

16. Carmona L, Cross M, Williams B, Lassere M. Rheumatoid arthritis. Best Pract Res Clin Rheumatol. 2010; 24(6): 733-745.
17. Fernandes L, Hagen BK, Bijlsma JW. et al. EULAR recommendations for non-pharmacological core management of hip and knee osteoarthiritis. Ann Rheum Dis. 2013; 72(7): $1125-1135$.

Artykuł przyjęty do redakcji: 21.02.2019.

Artykuł przyjęty do publikacji: 06.05.2019.

Źródło finansowania: Praca nie jest finansowana z żadnego źródła. Konflikt interesów: Autorzy deklarują brak konfliktu interesów.

\section{Adres do korespondencji:}

Piotr Jarzynkowski

ul. Dębinki 7

80-952 Gdańsk

tel. 583491247

e-mail.: piotr.jarzynkowski@gumed.edu.pl

Zakład Pielęgniarstwa Chirurgicznego, Wydział Nauk o Zdrowiu z Oddziałem Pielęgniarstwa i Instytutem Medycyny Morskiej i Tropikalnej, Gdański Uniwersytet Medyczny 